\title{
Effects of coastal managed retreat on mercury biogeochemistry
}

Article

Accepted Version

Sizmur, T., Godfrey, A. and O'Driscoll, N. J. (2016) Effects of coastal managed retreat on mercury biogeochemistry. Environmental Pollution, 209. pp. 99-106. ISSN 0269-7491 doi: https://doi.org/10.1016/j.envpol.2015.11.016 Available at https://centaur.reading.ac.uk/48003/

It is advisable to refer to the publisher's version if you intend to cite from the work. See Guidance on citing.

To link to this article DOI: http://dx.doi.org/10.1016/j.envpol.2015.11.016

Publisher: Elsevier

All outputs in CentAUR are protected by Intellectual Property Rights law, including copyright law. Copyright and IPR is retained by the creators or other copyright holders. Terms and conditions for use of this material are defined in the End User Agreement.

\section{www.reading.ac.uk/centaur}

\section{CentAUR}

Central Archive at the University of Reading

Reading's research outputs online 
1 Effects of coastal managed retreat on mercury biogeochemistry

2

3 Tom Sizmur $^{\mathrm{a}^{*}}$, Adam Godfrey ${ }^{\mathrm{a}}$ and Nelson J. O’Driscoll ${ }^{\mathrm{a}}$

4

$5 \quad{ }^{\mathrm{a}}$ Department of Earth \& Environmental Science, K.C. Irving Environmental Science Center,

6 Acadia University, Wolfville, NS, B4P 2R6, Canada.

7

$8 *$ Corresponding author

9 Present address: Soil Research Centre, Department of Geography and Environmental Science,

10 Russell Building, University of Reading, Reading, RG6 6DW, UK

11 E-mail: t.sizmur@reading.ac.uk

12 Phone: $+44(0) 1183788913$

13 


\section{Abstract}

15 We investigated the impact of managed retreat on mercury $(\mathrm{Hg})$ biogeochemistry at a site subject

16 to diffuse contamination with $\mathrm{Hg}$. We collected sediment cores from an area of land behind a

17 dyke one year before and one year after it was intentionally breached. These sediments were

18 compared to those of an adjacent mudflat and a salt marsh. The concentration of total mercury

19 (THg) in the sediment doubled after the dyke was breached due to the deposition of fresh

20 sediment that had a smaller particle size, and higher $\mathrm{pH}$. The concentration of methylmercury

$21(\mathrm{MeHg})$ was $27 \%$ lower in the sediments after the dyke was breached. We conclude that coastal

22 flooding during managed retreat of coastal flood defences at this site has not increased the risk of

$23 \mathrm{Hg}$ methylation or bioavailability during the first year. As the sediment becomes vegetated,

24 increased activity of $\mathrm{Hg}$-methylating bacteria may accelerate $\mathrm{Hg}$-methylation rate.

25 Keywords: Mercury, Methylmercury, Biogeochemistry, Sediment deposition, Coastal

26 Capsule: Mercury concentration doubled in sediments after coastal flooding but methylmercury

27 concentration deceased 
29 Coastal wetlands have been subject to dramatic global declines in the past due to dyking and

30 draining for agriculture. However, this practice is now being reversed in many countries because

31 salt marshes are valued as habitats for wildlife and as natural defence against rising sea-levels

32 (Singh et al., 2007). Managed retreat of coastal defences has led to an increase in the number of

33 sites where dykes are breached, agricultural fields are inundated with seawater, sediment is

34 deposited over soils, and new salt marshes are created. Inundation of previously dyked farmland

35 leads to considerable biogeochemical changes, characterised by increased salinity, lower redox

36 potential (Portnoy and Giblin, 1997) and a decaying mat of buried vegetation (Emmerson et al.,

37 2000). There is concern that biogeochemical changes during managed retreat may alter the fate

38 of redox-sensitive contaminants such as mercury (Hg) (Morris et al., 2014).

40 The Bay of Fundy in Southeastern Canada is renowned for having the largest tidal amplitude in

41 the world, which gives rise to expansive intertidal mudflats and vast areas of salt marsh (Crowell

42 et al., 2011; Desplanque and Mossman, 2004). For centuries the Bay's coastline has been

43 extensively dyked to use the land for agriculture (Wynn, 1979). The land surrounding the Bay of

44 Fundy is designated a 'biological mercury hotspot' due to elevated concentrations of $\mathrm{Hg}$ in biota

45 (Evers et al., 2007). The Bay of Fundy itself has been identified as an area of special concern for

$46 \mathrm{Hg}$ contamination because the Bay's ecosystem may be critical to concentrations of $\mathrm{Hg}$ found in

47 fish, birds and wildlife (Hung and Chmura, 2006). 
49 Mercury enters the Bay of Fundy through seawater inflow and atmospheric deposition

50 (Sunderland et al., 2012). The Hg present in sediments of the Bay of Fundy is strongly

51 associated with organic matter and fine textured sediments (O'Driscoll et al., 2011; Sizmur et al.,

52 2013b). Inorganic $\mathrm{Hg}$ in sediments can be converted to methylmercury ( $\mathrm{MeHg})$ under anoxic

53 conditions by sulphate-reducing bacteria (Compeau and Bartha, 1985). Methylmercury can

54 biomagnify through food webs (Lavoie et al., 2010) and is a potent neurotoxin affecting higher

55 trophic level animals and humans (Rasmussen et al., 2005).

57 Increases in MeHg concentrations in sediments and biota have been observed during the decades 58 that follow terrestrial freshwater flooding for dam construction or wetland creation (Kelly et al., 59 1997; Sinclair et al., 2012). However, little research has been done to assess changes in $\mathrm{Hg}$ 60 biogeochemistry after coastal wetland flooding. Terrestrial flooding events, like reservoir or 61 wetland creation, entail a permanent change in sediment redox from oxic to anoxic conditions 62 because the sediments are constantly flooded. However, coastal flooding events subject the land 63 to fluctuating oxic/anoxic conditions due to the tidal cycle. These fluctuations generate an oxic64 anoxic interface in the sediment. The temporal fluctuations in redox conditions increases the 65 volume of sediment where sulphate reduction and mercury methylation may occur (Heim et al., 66 2007; Sizmur et al., 2013a). However, there is also frequent tidal flushing of inundated areas 67 which acts as a significant means of removing $\mathrm{MeHg}$ from the surface of coastal sediments 68 (Guédron et al., 2012). Therefore, it is not clear if managed retreat will increase or decrease $\mathrm{Hg}$ 69 and $\mathrm{MeHg}$ concentrations in sediments. 
71 We investigated the effects of managed retreat on mercury biogeochemistry at Beaubassin

72 Research Station where a dyke has recently been breached, allowing the seawater to inundate

73 land previously drained for agriculture.

74

75 Materials and Methods

$76 \quad$ Site Description

77 Beaubassin Research Station (Latitude: 45.852195 Longitude: -64.279631) is located on the

78 Chignecto Isthmus between Nova Scotia and New Brunswick, Canada (Figure 1a). It lies along

79 the Cumberland Basin, a branch of Chignecto Bay, in the Bay of Fundy which is sourced from

80 the Gulf of Maine. The average tidal amplitude at Beaubassin is $11 \mathrm{~m}$ (Gordon Jr and Baretta,

81 1982). Recently, an eroding 150-year-old dyke was replaced with a new dyke built

82 approximately $90 \mathrm{~m}$ back from the pre-existing coastline in order to protect transport

83 infrastructure and the historic site of Fort Beausejour from tidal surges. The 40 ha of low lying

84 land between the old dyke and the new dyke (Latitude: 45.851595 Longitude: -64.294379) was

85 flooded in October 2010. Flooding occurred when the old dyke was deliberately breached so that

86 sediment could accumulate to protect the new dyke before the old dyke completely failed

87 (Ollerhead et al., 2011). Tidal re-entry has resulted in the rapid deposition of fresh sediment over

88 the top of the agricultural soil, burying a mat of terrestrial vegetation. At the time of sampling,

89 new salt marsh vegetation was yet to establish. 
(a)

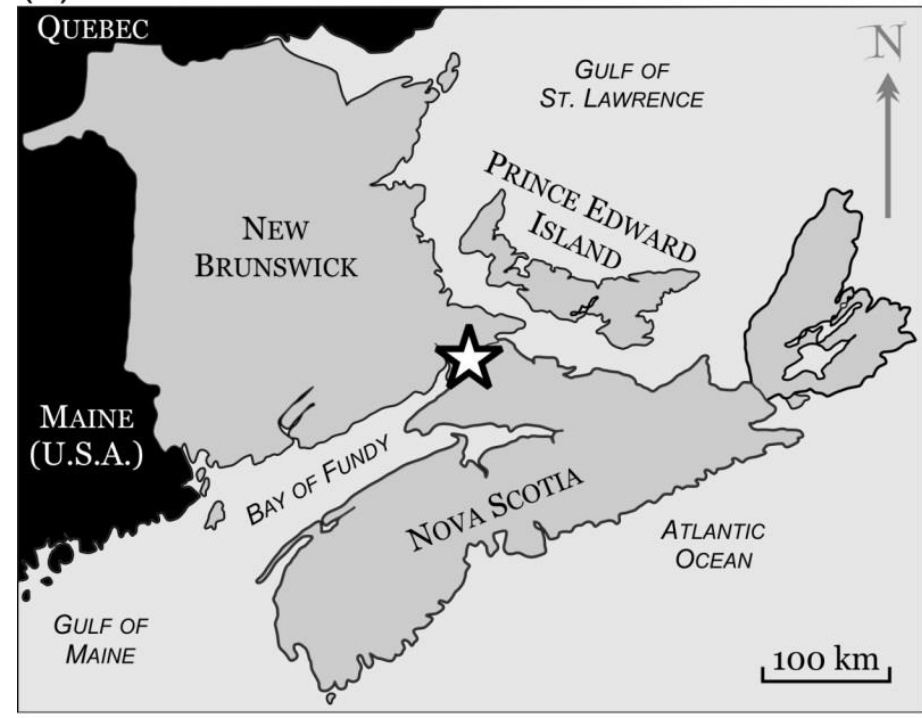

(c)

है (b)

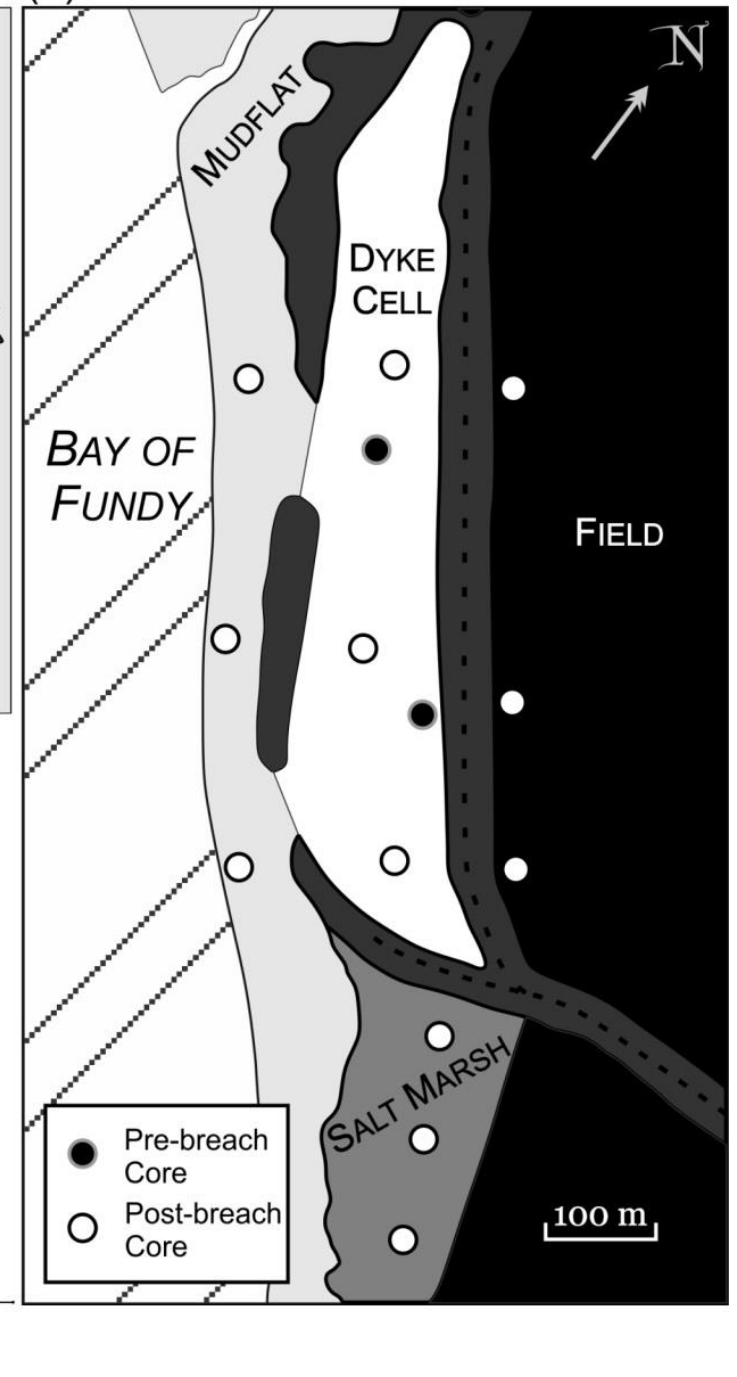

91 Figure 1. (a) Site location at Beaubassin, New Brunswick, Canada; (b) Location of all

92 cores sampled from the dyke cell (pre-breach and post-breach) along with adjacent

93 sites (mudflat, salt marsh and field). The location of two gaps in the wall of the dyke cell

94 represent where they were deliberately breached in 2010; (c) Electrical conductivity of

95 sediment cores sampled (averaged $0-15 \mathrm{~cm}$ ) shown here to demonstrate the influence

96 of seawater on the dyke cell pre-breach and post-breach. 
99 Two $16 \mathrm{~cm}$ deep cores were taken in the dyke cell (Figure 1b) between the new and the old 100 dykes (hereafter referred to as the pre-breach cores) in summer 2009 (before the old dyke was 101 breached in 2010). We returned to the site in summer 2011 to collect cores one year after the old 102 dyke was breached. Three $15 \mathrm{~cm}$ deep cores were sampled at four locations: (i) The area 103 previously sampled in the dyke cell between the new and old dykes (hereafter referred to as the 104 post-breach cores), (ii) the mudflat seaward of the dyke cell, (iii) a pre-existing salt marsh 105 adjacent to the dyke cell, and (iv) the field landward of the dyke cell (Figure 1b). All cores were 106 sampled at low tide using polyvinyl chloride (PVC) cores $(10 \mathrm{~cm}$ internal diameter) that were 107 dug out with a stainless steel spade.

Pre-breach cores were sliced in $2 \mathrm{~cm}$ intervals to a depth of $16 \mathrm{~cm}$, producing a total of eight

110 slices per core. Each of the post-breach, mudflat, salt marsh, and field cores were sliced at $1 \mathrm{~cm}$

111 intervals for the upper $5 \mathrm{~cm}$ of sediment and then at $2 \mathrm{~cm}$ intervals for the remaining $10 \mathrm{~cm}$,

112 producing a total of 10 core slices per core. Core slices were individually sealed in Ziploc bags at 113 the research station and placed in a dark cooler with ice packs for transport back to the 114 laboratory.

116 At the laboratory each sediment slice was thoroughly homogenised by hand in the Ziploc bag 117 and frozen as a wet homogenate at $-20{ }^{\circ} \mathrm{C}$. Sediment samples were later thawed and a subsample 118 dried at $60{ }^{\circ} \mathrm{C}$ for 24 hours. Dried sediment samples were ground with a pestle and mortar and 119 sieved to $<2 \mathrm{~mm}$. A subsample of wet sediment was analysed for electrical conductivity (EC) 
120 using a VWR Symphony SP90M5 meter and Orion electrical conductivity probe. The field was

121 only sampled to demonstrate that the pre-breach sediments had not been inundated by seawater

122 prior to the breach. Since the EC of the pre-breach and field cores (Figure 1c) revealed no

123 significant difference $(\mathrm{p}>0.05)$, further analysis of the field cores was deemed unnecessary.

124 Each slice of the remaining cores was analysed for total mercury ( $\mathrm{THg}), \mathrm{MeHg}$, percentage

125 organic matter (\%OM), particle size distribution, water-extractable organic carbon (WEOC) and $126 \mathrm{pH}$.

127

$128 \quad$ Analytical Procedures

129 Total mercury in sediment was determined using thermal degradation - gold amalgamation 130 atomic absorbance spectroscopy as outlined in EPA Method 7473 (1998) using a Nippon MA1312000 non-dispersive double-beam cold-vapor atomic absorption $\mathrm{Hg}$ analyzer. Methylmercury 132 was determined in sediments by alkaline digestion, ethylation purge and trap Gas 133 Chromatography - Cold Vapour Atomic Fluorescence Spectrometry (GC-CVAFS) following 134 Sizmur et al (2013b). A $100 \mathrm{mg}$ sample of sediment was digested in $2.5 \mathrm{ml}$ of basic methanol (25 $135 \% \mathrm{KOH} / \mathrm{MeOH}$ ) by shaking on a reciprocal shaker for 1 hour and then heating for 1 hour at 90 $136{ }^{\circ} \mathrm{C}$. Within 24 hours of digestion, a $60 \mu \mathrm{l}$ aliquot was transferred to a glass reaction bubbler, 137 ethylated with $\mathrm{NaB}\left(\mathrm{C}_{2} \mathrm{H}_{5}\right)_{4}$, purged with argon, collected on a Tenax trap and analysed for $\mathrm{MeHg}$ 138 using GC-AFS (Brooks Rand Model III).

140 Organic matter in sediment was determined by loss on ignition at $500{ }^{\circ} \mathrm{C}$ (Byers et al., 1978) and 141 particle size distribution by the micro-pipette method (Miller and Miller, 1987). Sand was 
142 calculated as particles $2000-63 \mu \mathrm{m}$, silt as 63-2 $\mu \mathrm{m}$, and clay as $<2 \mu \mathrm{m}$ in diameter. Water-

143 extractable organic carbon was determined following Sizmur et al (2011) by shaking $1 \mathrm{~g}$ of

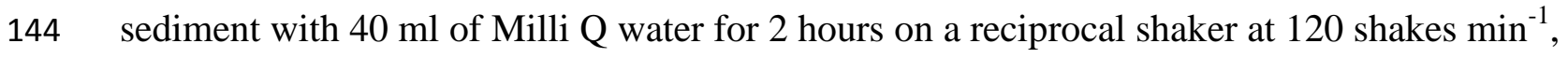

145 followed by centrifuging at $4000 \mathrm{rpm}(2647 \mathrm{G})$ for $20 \mathrm{~min}$ and filtering to $<0.45 \mu \mathrm{m}$ with

146 polypropylene membrane filters, before TOC/TIC analysis with a Shimadzu TOC-V CPH Total

147 Organic Carbon Analyzer. Sediment $\mathrm{pH}$ was analysed in WEOC vials prior to centrifuging.

\section{Quality control}

150 Sediments were analysed in triplicate alongside certified reference materials MESS-3 (National

151 Research Council Canada) and SQC-1238 (Sigma Aldrich RTC) for THg and MeHg

152 respectively. Mean recovery of THg from MESS-3 was 102.2 \% (SD = 1.4\%). Mean recovery of

$153 \mathrm{MeHg}$ from SQC-1238 was $94.4 \%(\mathrm{SD}=12.0 \%)$. Detection limits for $\mathrm{MeHg}$ and $\mathrm{THg}$ were

1540.65 and $1.21 \mathrm{pmol} \mathrm{g}^{-1}$, respectively. Both samples and reference materials during $\mathrm{Hg}$ analysis

155 were corrected for background by subtracting averaged method blanks from the analysed

156 samples.

\section{$157 \quad$ Statistical Analysis}

158 Statistical analysis was carried out using Genstat version 16. Normality and homoscedasticity 159 was assessed by inspecting residual plots. Two-way analysis of variance was carried out on all 160 data (MeHg, THg, pH, clay, \%OM, WEOC and EC) using 'site' and 'depth' as the factors and 161 allowing for interactions. Fisher's least significant difference was used to identify differences

162 between individual treatments. Multiple linear regression was carried out by forward selection; 163 first the variable that resulted in the highest $\mathrm{R}^{2}$ values was included in the model, then variables 
164 that resulted in the greatest increase were added. Data presented in text as average values at each

165 site are calculated from the concentrations in cores averaged across all depths. All the raw data is 166 provided in the supporting information.

168 Results

169

\section{Mercury and Methylmercury}

170 The average concentration of THg in the post-breach cores was $85.1 \mathrm{pmol} \mathrm{g}^{-1}(\mathrm{SD}=15.6)$ which

171 was approximately double the concentration in the pre-breach cores $\left(41.1 \mathrm{pmol} \mathrm{g}^{-1}, \mathrm{SD}=9.52\right)$.

$172 \mathrm{THg}$ decreased significantly $(\mathrm{p}<0.001)$ with depth (Table 1$)$ in the post-breach and mudflat

173 cores but this decrease was not observed in the pre-breach or the salt marsh cores (Figure 2). The

$174 \mathrm{THg}$ concentration in the salt marsh cores was significantly $(\mathrm{p}<0.05)$ greater than the mudflat or

175 the dyke cell pre- or post-breach. The post-breach cores had significantly $(\mathrm{p}<0.05)$ greater $\mathrm{Hg}$

176 concentrations than the pre-breach cores.

177 Table 1 Analysis of variance from physiochemical sediment variables; Water Extractable 178 Organic Carbon (WEOC), pH, Electrical Conductivity (EC), Clay content and Organic Matter 179 (OM).

\begin{tabular}{llll} 
Variable & Site F value & Depth F value & $\begin{array}{l}\text { Site-depth } \\
\text { interaction F value }\end{array}$ \\
\hline $\mathrm{THg}$ & $62.19^{* * *}$ & $2.34^{*}$ & 0.41 \\
$\mathrm{MeHg}$ & $12.83^{* * *}$ & $2.06^{*}$ & 0.55 \\
$\% \mathrm{MeHg}$ & $31.41^{* * *}$ & $0.95^{*}$ & 0.62 \\
$\% \mathrm{OM}$ & $15.03^{* * *}$ & 0.29 & 0.93 \\
$\mathrm{pH}$ & $16.87^{* * *}$ & $0.97^{*}$ & 0.79 \\
$\% \mathrm{Clay}$ & $24.93^{* * *}$ & 1.74 & 0.38 \\
WEOC & $32.14^{* * *}$ & 1.68 & 1.36 \\
$\mathrm{EC}$ & $69.15^{* * *}$ & 0.82 & 1.23 \\
\hline
\end{tabular}

${ }^{\star}=\mathrm{p}<0.05,{ }^{\star * *}=\mathrm{p}<0.001$ 

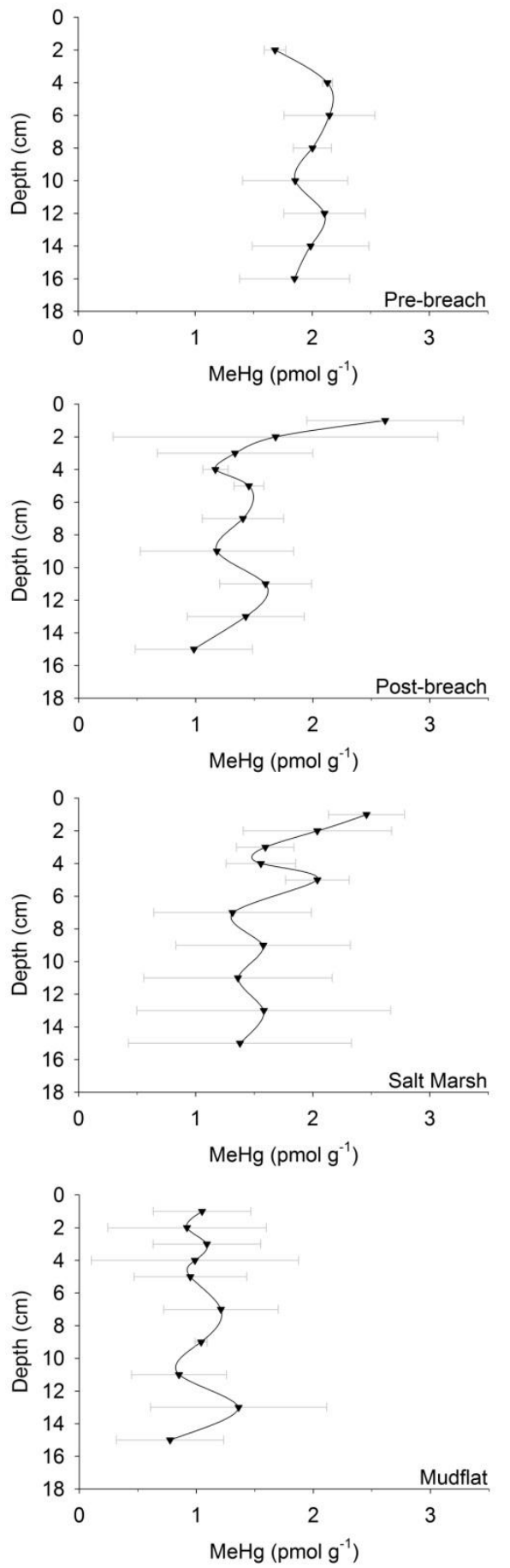
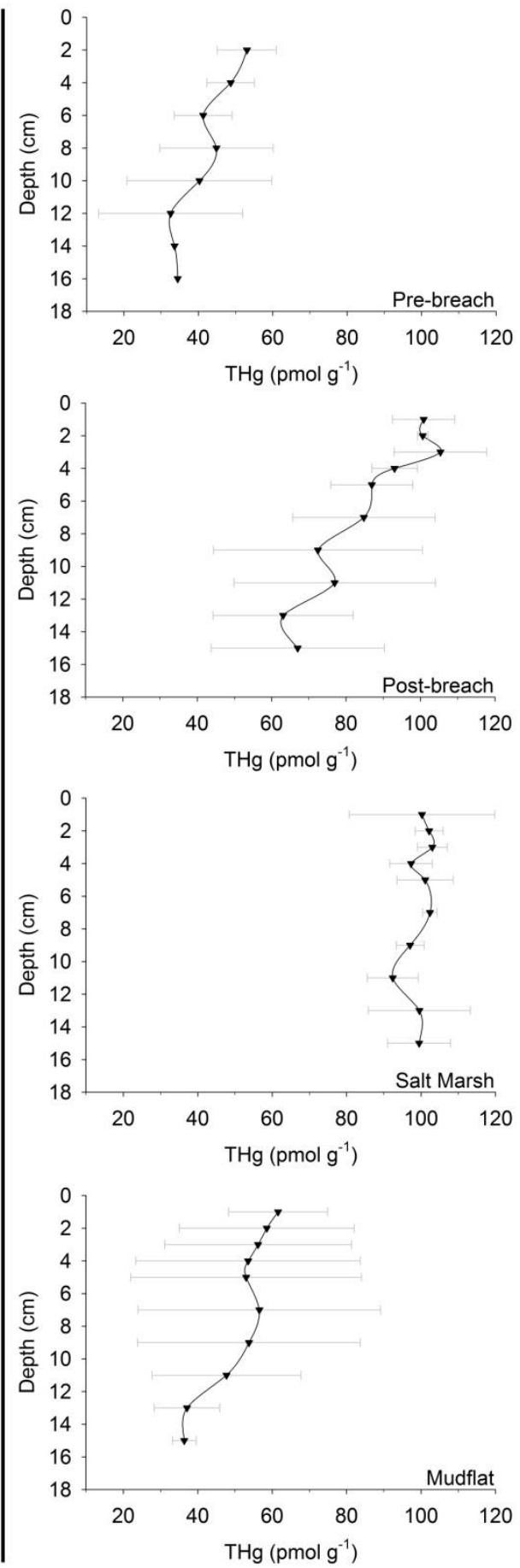

182 Figure 2. Total mercury $(\mathrm{THg})$ and methylmercury $(\mathrm{MeHg})$ concentrations of sediment

183 slices of cores sampled from the dyke cell (pre-breach and post-breach) along with 184 adjacent sites (mudflat and salt marsh). The error bars represent the standard deviation 185 of three replicate cores ( $n=2$ for the pre-breach cores). 
MeHg significantly ( $\mathrm{p}<0.05$ ) decreased with depth (Table 1) in the post-breach and salt marsh cores (Figure 2). Although THg was greater after inundation, MeHg concentration was significantly $(\mathrm{p}<0.05)$ lower in post-breach sediments (Figure 2). Methylmercury concentrations were $27 \%$ lower in the post-breach cores $\left(1.48 \mathrm{pmol} \mathrm{g}^{-1}, \mathrm{SD}=0.54\right)$ compared to the pre-breach cores $\left(1.97 \mathrm{pmol} \mathrm{g}^{-1}, \mathrm{SD}=0.31\right)$. However, we did measure $36 \%$ higher $\mathrm{MeHg}$ concentrations in the upper $2 \mathrm{~cm}$ of the post-breach sediment than in the top $2 \mathrm{~cm}$ of the prebreach cores (Figure 2). The post-breach MeHg concentration was not significantly $(\mathrm{p}>0.05)$ different than that measured in the salt marsh $\left(1.69 \mathrm{pmol} \mathrm{g}^{-1}, \mathrm{SD}=0.60\right)$ but was significantly $(\mathrm{p}$ $>0.05)$ greater than MeHg in the mudflat $\left(1.02 \mathrm{pmol} \mathrm{g}^{-1}, \mathrm{SD}=0.51\right)$. The percentage of $\mathrm{MeHg}$ as a proportion of the $\mathrm{THg}(\% \mathrm{MeHg})$ was significantly $(\mathrm{p}<0.05)$ greater in the pre-breach cores $(5.97 \%, \mathrm{SD}=2.99)$ than the post-breach cores $(2.02 \%, \mathrm{SD}=0.58) . \% \mathrm{MeHg}$ in the post-breach sediment was not significantly $(\mathrm{p}>0.05)$ different from the mudflat $(2.34 \%)$ or salt marsh $(1.84 \%)$ sediments.

\section{Physiochemical variables}

The EC of the pre-breach cores was not significantly different to the samples taken from the field behind the new dyke. EC was significantly increased $(\mathrm{p}<0.05)$ by periodic tidal inundation of the dyke cell, increasing over $2000 \%$ from pre- to post-breach (Figure 1c). Post-breach sediment EC was also significantly $(\mathrm{p}<0.05)$ greater than the salt marsh and mudflat but the magnitude of the difference was much smaller.

Sediment $\mathrm{pH}$ was significantly $(\mathrm{p}<0.001)$ greater after inundation of the dyke cell, rising from 5. $08(\mathrm{SD}=1.2)$ in the pre-breach cores to $7.43(\mathrm{SD}=0.6)$ in the post-breach cores (Figure 3$)$. 
209 There was no significant $(\mathrm{p}>0.05) \mathrm{pH}$ difference between the post-breach cores and the salt 210 marsh or mudflat cores.

212 The texture of the sediment in the top $15 \mathrm{~cm}$ of the dyke cell significantly $(\mathrm{p}<0.001)$ changed

213 during salt marsh restoration as fresh sediment with a smaller particle size distribution was

214 deposited over the top of the drained agricultural field (Figure 3). Percentage clay was

215 significantly $(\mathrm{p}<0.05)$ greater and sand significantly $(\mathrm{p}<0.05)$ lower in the sediment after the 216 inundation. Percentage clay in the post-breach cores $(29.8 \%, \mathrm{SD}=1.52)$ was nearly double that

217 in the pre-breach cores $(16.6 \%, \mathrm{SD}=13.8)$. The proportions of sand, silt and clay in the post-

218 breach cores were not significantly $(\mathrm{p}>0.05)$ different to the sediments sampled from the

219 mudflat (Figure 3) but clay content was significantly $(\mathrm{p}<0.05)$ greater than sediments sampled 220 from the salt marsh.

222 The post-breach sediments had significantly $(\mathrm{p}<0.05)$ higher organic matter $(\% \mathrm{OM})$ and WEOC

223 than the pre-breach cores (Table 1 and Figure 3). There was no significant $(\mathrm{p}>0.05)$ difference

224 between the post-breach cores and the salt marsh and mudflat cores, for either \%OM or WEOC.

225 The concentration of both WEOC $\left(44.9 \mathrm{mmol} \mathrm{kg}^{-1}, \mathrm{SD}=4.64\right)$ and $\% \mathrm{OM}(6.3 \%, \mathrm{SD}=0.8)$ in

226 the post-breach cores was greater than the mudflat cores $\left(32.1 \mathrm{mmol} \mathrm{kg}^{-1}, \mathrm{SD}=8.87\right.$ and $5.8 \%$,

$227 \mathrm{SD}=1.2)$ but lower than the salt marsh cores $\left(47.9 \mathrm{mmol} \mathrm{kg}^{-1}, \mathrm{SD}=7.17\right.$ and $\left.6.7 \%, \mathrm{SD}=0.7\right)$. 

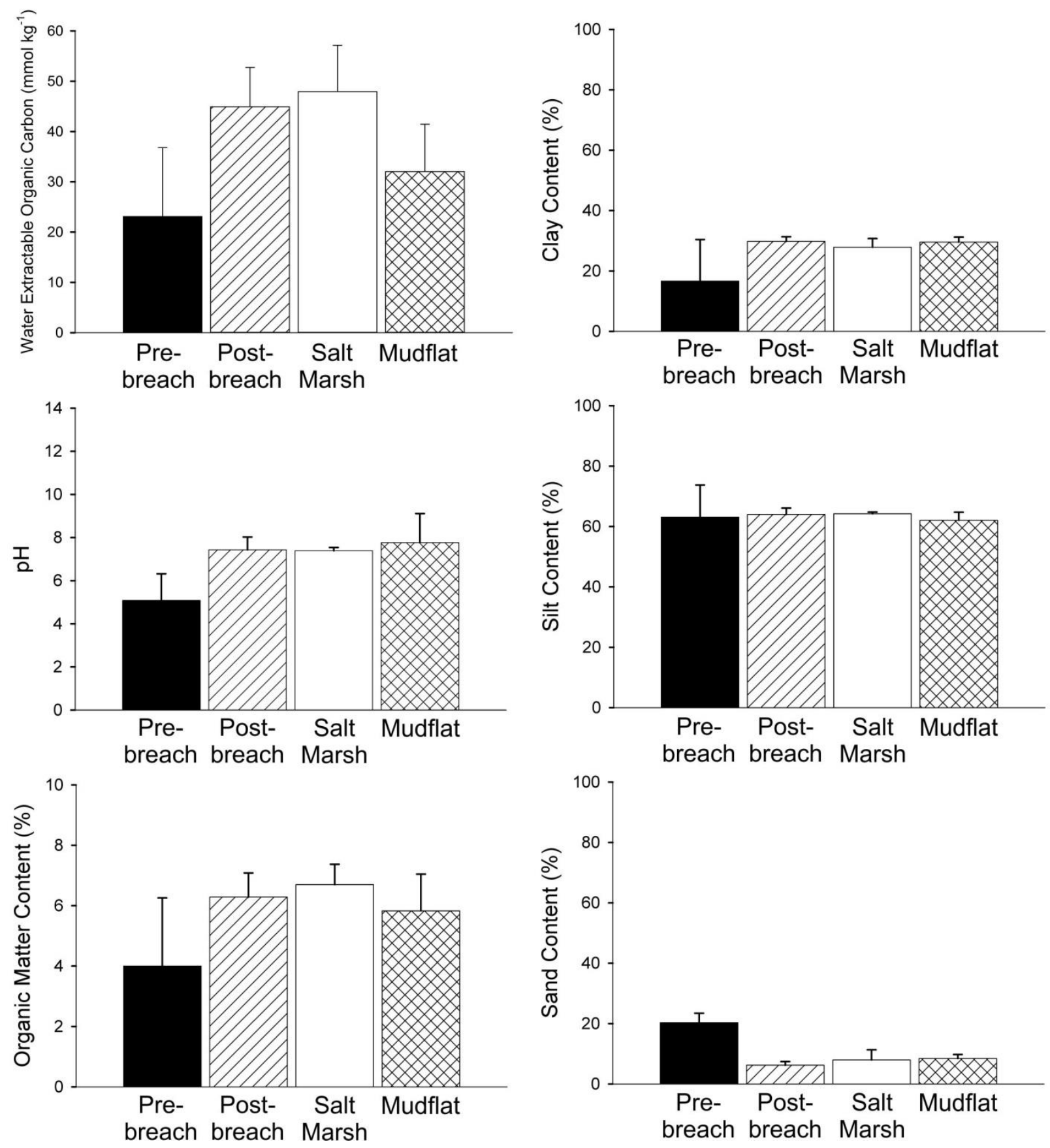

229 Figure 3. Physiochemical variables measured in cores (averaged 0-15 cm) sampled 230 from the dyke cell (pre-breach and post-breach) along with adjacent sites (mudflat and 231 salt marsh). The error bars represent standard deviation of three replicate cores ( $n=2$ 232 for the pre-breach cores). 
235 The correlation between the best multiple linear regression model and the $\mathrm{THg}$ concentrations 236 measured in the sediments (Figure 4) yielded an $\mathrm{R}^{2}$ value of 0.524 and a p value $<0.001$ (Table

237 2). The explanatory variables in order of decreasing importance were WEOC, $\mathrm{pH}, \mathrm{EC}$ and

$238 \%$ Clay. Adding the next most important variable (\%OM) decreased the $\mathrm{R}^{2}$ value to 0.519 .

239 WEOC alone explained $36.7 \%$ of the variation in the observed data.

240 Table 2 Significance and correlation results of forward multiple linear regression models for the 241 prediction of $\mathrm{THg}$ and $\mathrm{MeHg}$ from physiochemical sediment variables; Water Extractable 242 Organic Carbon (WEOC), pH, Electrical Conductivity (EC), Clay content and Organic Matter 243 (OM).

\begin{tabular}{llll} 
Response variable & Fitted terms & $\mathrm{F}$ value & $\mathrm{R}^{2}$ \\
\hline $\mathrm{THg}$ & WEOC & $61.8^{* * *}$ & 0.367 \\
& WEOC+pH & $48.6^{* * *}$ & 0.476 \\
& WEOC+pH+EC & $35.5^{* * *}$ & 0.496 \\
& WEOC+pH+EC+Clay & $29.9^{* * *}$ & 0.524 \\
\hline $\mathrm{MeHg}$ & EC & $7.02^{* *}$ & 0.54 \\
& EC+THg & $8.36^{* * *}$ & 0.123 \\
& EC+THg+pH & $7.07^{* * *}$ & 0.148 \\
& EC+THg+pH+Clay & $6.05^{* * *}$ & 0.161 \\
& EC+THg+pH+Clay+WEOC & $5.50^{* * *}$ & 0.176 \\
& EC+THg+pH+Clay+WEOC+OM & $6.56^{* * *}$ & 0.241 \\
\hline${ }^{* *}=\mathrm{p}<0.01,{ }^{* * *}=\mathrm{p}<0.001$ & &
\end{tabular}

245 The variability in $\mathrm{MeHg}$ concentrations was more difficult to explain than the $\mathrm{THg}$

246 concentrations using the physiochemical variables measured. The multiple linear regression

247 model for MeHg (Figure 4) had a lower $\mathrm{R}^{2}$ value than the model for $\mathrm{THg}$. The fit which included 248 EC, THg, pH, \%Clay, WEOC and \%OM (in order of decreasing importance) had an $\mathrm{R}^{2}$ value of 2490.241 and a p value of $<0.001$. Although EC accounted for the greatest extent of the variability 250 in the MeHg dataset, when considered on its own EC accounted for only $5.4 \%$ of the variation.

251 This indicates that variables that we measured could not adequately explain the concentration of $252 \mathrm{MeHg}$ in the sediments. 

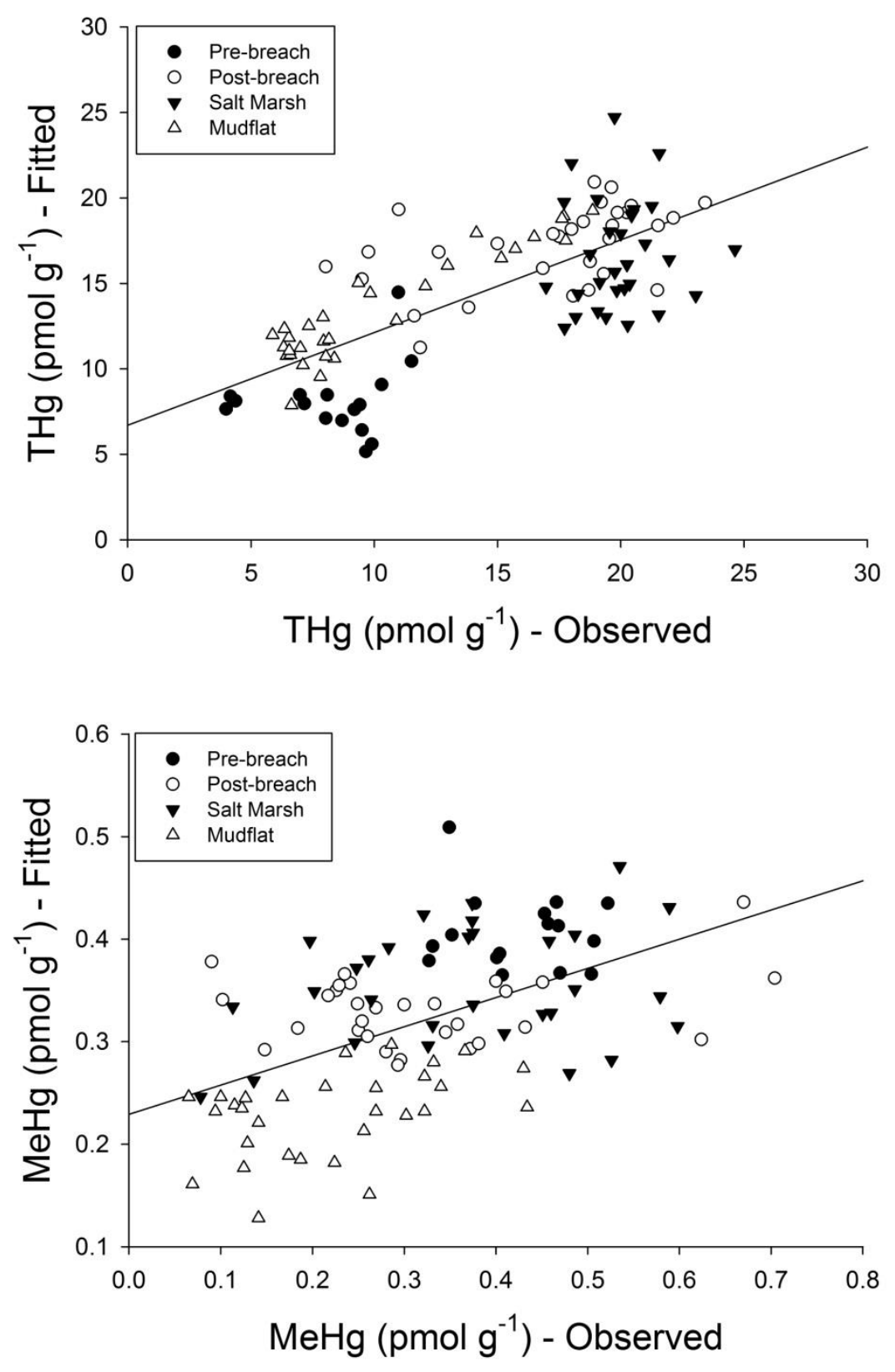

254 Figure 4. Total mercury $(\mathrm{THg})$ and methylmercury $(\mathrm{MeHg})$ concentrations observed in 255 cores sampled from the dyke cell (pre-breach and post-breach) along with adjacent 256 sites (mudflat and salt marsh) plotted against fitted $\mathrm{THg}$ and $\mathrm{MeHg}$ concentrations that 257 were predicted using multiple linear regression models (Table 2) created with the same 258 data. The THg model included WEOC, pH, EC, and \%Clay as explanatory variables, 259 explaining $51.9 \%$ of the variability. The $\mathrm{MeHg}$ model included $\mathrm{EC}, \mathrm{THg}, \mathrm{pH}, \% \mathrm{Clay}$, 260 WEOC and $\% O M$ as explanatory variables, explaining $24.1 \%$ of the variability. 


\section{$\underline{\text { Discussion }}$}

Post-breach sediments are chemically more similar to the salt marsh and mudflat than pre-

\section{breach sediments}

The breaching of the dyke and inundation of the dyke cell deposited a large quantity of fresh sediment over the top of the pre-existing soil. This event changed the biogeochemistry of the system by increasing the EC, $\mathrm{pH}, \% \mathrm{OM}$ and WEOC. The impact of this change is best demonstrated by the considerable increase in the EC observed (Figure 1c) as the dyke cell changed from a terrestrial environment to a coastal environment due to inundation with saline water. While the topography of the mudflat and the salt marsh gently slopes down towards the sea, the soil in the dyke cell was relatively flat prior to breaching and inundation. The deposition of fresh sediment in the dyke cell was unevenly distributed leaving puddles of seawater which we observed in depressed areas at low tide. Evaporation of water and precipitation of salts in these depressed areas (Mouneimne and Price, 2007) has resulted in the EC of the post-breach sediments being elevated above levels measured in the mudflat or the salt marsh (Figure 1c).

The objective of the managed retreat is for salt marsh vegetation to colonise the freshly deposited sediment once the depth of the sediment raises the wetland to an elevation high enough for vegetation to survive (Williams and Orr, 2002). During the post-breach sampling in 2011 the dyke cell was still unvegetated and looked more similar to a mudflat than a salt marsh. This observation is supported by the textural analysis of the sediment deposited in the dyke cell (postbreach) which was similar to the sediment sampled from the mudflat (Figure 3). The chemistry of the post-breach sediments (WEOC, $\mathrm{pH}$ and \%OM) was more similar to the salt marsh and 
283 mudflat sediments than the samples collected pre-breach. However, this data must be interpreted 284 with caution since only two cores were collected prior to the dyke being breached.

288 The total Hg concentrations in the reclaimed region were similar to those found in other studies 289 of non-vegetated intertidal mudflats (O’Driscoll et al., 2011; Sizmur et al., 2013b) and salt 290 marshes (Hung and Chmura, 2006; Sunderland et al., 2004) in the Bay of Fundy. Over a period

291 of two years (and only one year after the dyke was breached) the concentration of total $\mathrm{Hg}$ in the 292 dyke cell was considerably greater (Figure 2). We acknowledge, however, that this dataset has 293 limitations since there were only two replicate cores collected prior to the dyke being breached. 294 Despite this apparent increase, the concentration of $\mathrm{Hg}$ in the post-breach sediments had not yet 295 reached that of the salt marsh, which is the target ecosystem. There was a clear decrease in $\mathrm{Hg}$ 296 concentration with sediment depth in both the mudflat and the post-breach sediments but not in 297 the salt marsh sediments which is a further indication that the sediment characteristics more 298 closely match the mudflat at this stage of restoration.

300 While the total $\mathrm{Hg}$ concentrations were greater in the dyke cell after inundation, and the $\mathrm{MeHg}$ 301 concentrations were greater at the surface of the sediment, $\mathrm{MeHg}$ was observed to be lower 302 overall in the post-breach cores (Figure 2). This lower MeHg concentration was reflected by $303 \% \mathrm{MeHg}$ in the sediments of the dyke cell decreasing from $6 \%$ pre-breach to $2 \%$ post-breach 304 when averaged over all the depths. This observation indicates that methylation has not rapidly 
occurred in the newly deposited $\mathrm{Hg}(\mathrm{II})$ species in the sediment. If the lower $\mathrm{MeHg}$ in the postbreach sediments was due to greater export of $\mathrm{MeHg}$ from the sediments by tidal flushing then we would have expected to see $\mathrm{MeHg}$ depleted in the top few $\mathrm{cm}$ of sediment. However, $\mathrm{MeHg}$ concentrations were greatest in the top few $\mathrm{cm}$ (Figure 2). Therefore, tidal flushing is probably not the reason for the lower MeHg in the post-breach sediments.

Because total $\mathrm{Hg}$ concentrations are greater post-breach and $\mathrm{MeHg}$ concentrations are lower, $\mathrm{Hg}$ methylation cannot be limited by the supply of total $\mathrm{Hg}$. $\mathrm{Hg}$ methylation is rather limited by the bioavailability of $\mathrm{Hg}$ to $\mathrm{Hg}$ methylating bacteria or the activity of these bacteria (Sunderland et al., 2006). Canário et al. (2007) showed that \% MeHg in unvegetated coastal wetland sediments were only $0.6 \%$, while vegetated sediments had up to $18 \% \mathrm{MeHg}$. The authors explained that this discrepancy is likely to occur because the presence of vegetation increases microbial activity and favours $\mathrm{Hg}$ methylation. Colonisation of the dyke cell by benthic invertebrates (e.g. polychaete worms) may also increase the sediment-water interface and the concentration of MeHg in their burrows (Sizmur et al., 2013a). Therefore, the MeHg concentrations in the dyke cell may increase as the restoration progresses and the dyke cell becomes colonised by vegetation and fauna. This prediction must be contrasted with the observation by Morris et al. (2014) that restored salt marshes have lower MeHg concentrations several decades after inundation when compared to adjacent natural salt marshes. It is therefore unclear whether the $\mathrm{MeHg}$ concentration in the dyke cell sediments will increase beyond the concentrations in the adjacent natural salt marsh in the long term. 

concentrations are poorly predicted

329 Water-extractable organic carbon, $\mathrm{pH}, \mathrm{EC}$, and clay content of sediments all contributed to the multiple linear regression models that explained $52.4 \%$ of the variability associated with the concentration of $\mathrm{THg}$, but only $24 \%$ of the variability associated with $\mathrm{MeHg}$ concentrations in

332 the sediments (Table 2 and Figure 4). Clay content was positively correlated with THg sediment 333 concentration. A reduction in sediment particle size (here observed by an increase in clay 334 content) increases the surface-area-to-volume ratio of particulates in a system. The high surface 335 area and cation exchange capacity of clays results in the adsorption of $\mathrm{Hg}$ to fine particles 336 (Bengtsson and Picado, 2008). Suspension of fine sediments in the tidal water increases the 337 likelihood of sediments to scavenge $\mathrm{Hg}$ from the water column by settling and retaining $\mathrm{Hg}$ in 338 the accumulating sediment (Covelli et al., 2009; Hung and Chmura, 2006; Sunderland et al., 339 2006). Sediments comprised of fine particles also increase the proportion of particle-bound $\mathrm{Hg}$ 340 (Bengtsson and Picado, 2008) and may thus reduce the bioavailability of $\mathrm{Hg}$ to methylating 341 bacteria.

Dissolved organic matter (DOM) is a major binding phase for $\mathrm{Hg}$ in aquatic environments

344 (Haitzer et al., 2002; Haverstock et al., 2012; Le Faucheur et al., 2014; O'Driscoll and Evans, 345 2000; Ravichandran, 2004). Here we use WEOC as a proxy for DOM in the sediments following 346 Sizmur et al (2013b). Although we found a positive correlation between $\mathrm{THg}$ and both \%OM and 347 WEOC, the WEOC explains the THg concentration in the sediments better (Table 2). This 348 observation indicates that the changes in $\mathrm{Hg}$ in the sediments are due to a greater fraction that is 349 bound to soluble carbon complexes. The concentration of WEOC in the post-breach sediments 
350 (Figure 3) was higher than the mudflat and (unlike the salt marsh) was not associated with

351 vegetation growing in situ. It is therefore likely that the cause of higher concentrations of WEOC

352 (and $\mathrm{THg}$ ) in the post-breach sediments, compared to the mudflat, is the decaying mat of

353 terrestrial vegetation underneath the freshly deposited sediment. Hg complexation with DOM

354 reduces the bioavailability of $\mathrm{Hg}$ to methylating bacteria because the complexes are generally too

355 large to penetrate their biological membranes (Le Faucheur et al., 2014; Ravichandran, 2004).

356 However, soluble organic matter also provides an energy source for methylating bacteria and

357 may increase their activity resulting in greater methylation rates (Ullrich et al., 2001). Further

358 increases in DOM (and microbial activity) are likely to occur as the dyke cell becomes vegetated

359 (Canário et al., 2007) which may increase methylation rates in the future. The deposition of

360 plankton is likely to increase the $\% \mathrm{MeHg}$ in the fresh sediment as they contain approximately

$3616 \%$ to $15 \% \mathrm{MeHg}$ in the Northwest Atlantic Ocean (Hammerschmidt et al., 2013).

363 The solubility and speciation of $\mathrm{Hg}$ and the binding of dissolved $\mathrm{Hg}$ species to DOM or sediment

364 particles is $\mathrm{pH}$ dependent (Gabriel and Williamson, 2004). At low $\mathrm{pH}, \mathrm{H}^{+}$competes with $\mathrm{Hg}$ for

365 binding sites on DOM or the surface of sediment particles, which releases $\mathrm{Hg}$ into solution but

366 they also both compete for uptake by negatively charged bacterial cells. In this study $\mathrm{pH}$

367 correlated positively with $\mathrm{Hg}$ but negatively with $\mathrm{MeHg}$. This contrast indicates that the greater

$368 \mathrm{pH}$ of the mudflat, salt marsh, and post-breach sediments, compared to pre-breach sediments

369 (Figure 3) resulted in greater $\mathrm{Hg}$ retention (Hung and Chmura, 2006) but may have reduced $\mathrm{Hg}$

370 bioavailability to methylating bacteria (Barkay et al., 1997; Gilmour and Henry, 1991; Le

371 Faucheur et al., 2014). 
373 The increase in EC that resulted from the inundation of the dyke cell with sea water (Figure 1c)

374 is due to the high salinity of the seawater (Mouneimne and Price, 2007). The high salinity of the

375 sediment deposited after the dyke cell was inundated with seawater created an environment with

376 a higher ionic strength. As ionic strength increases, the concentration of $\mathrm{Hg}$ desorbed into

377 solution decreases (Duarte et al., 1991) resulting in greater $\mathrm{Hg}$ retention in sediments and a

378 decrease in the bioavailability of $\mathrm{Hg}$ to methylating bacteria (Barkay et al., 1997). Seawater

379 contains high concentrations of chloride ions which can form strong $\left(\log _{10} \mathrm{~K}_{1}{ }^{\circ}=7.31\right)$

380 complexes with mercury species (Powell et al., 2005). The greater the concentration of chloride,

381 the more negatively charged mercuric chloride ions $\left(\mathrm{HgCl}_{3}{ }^{-}\right.$and $\left.\mathrm{HgCl}_{4}{ }^{2-}\right)$ will be present in

382 solution and these negative ions also have a lower bioavailability (Barkay et al., 1997) to

383 methylating bacteria with negatively charged cell walls. Therefore, the increase in ionic strength

384 and formation of trivalent or tetravalent mercuric chloride species in the high EC sediments of

385 the post-breach sediments may have reduced their bioavailability to mercury methylating

386 bacteria. These $\mathrm{Hg}$-chloride complexes may also be less susceptible to photoreduction and loss to

387 the atmosphere (Qureshi et al., 2009).

389 In summary, the chemical changes that occur in the sediment after inundation may have

390 impacted on the bioavailability of $\mathrm{Hg}$ to methylating bacteria. The decrease in particle size

391 distribution and subsequent increase in sediment surface area may have increased sorption of $\mathrm{Hg}$

392 out of the water column but lowered its bioavailability. Higher organic matter levels may provide

393 a food source for methylating bacteria and increase their activity. Greater soluble organic carbon

394 may mobilise $\mathrm{Hg}$ from the surface of sediments but also complex it in a form that is unavailable

395 to methylating bacteria. An increase in sediment $\mathrm{pH}$ increases the concentration that can be 
396 adsorbed from the solution phase and reduces the bioavailability. Finally, the higher ionic

397 strength leads to a greater proportion of inorganic complexes and a lower bioavailability of $\mathrm{Hg}$.

398 This final conclusion assumes that the uptake of $\mathrm{Hg}$ by methylating bacteria occurs by passive

399 diffusion of neural or ionic lipophilic $\mathrm{Hg}$ species but there is now a considerable body of

400 evidence to suggest that uptake may occur by facilitated diffusion or active transportation by

401 protein pumps (Hsu-Kim et al., 2013).

402

403 Conclusions and Implications for Coastal Managed Retreat

404 Despite a doubling of $\mathrm{Hg}$ concentration within the dyke cell after the dyke was breached, $\mathrm{Hg}$ 405 concentrations are still below the Canadian Sediment Quality Guidelines (CCME, 2002). The 406 reason for the $\mathrm{Hg}$ increase in this study was the fresh deposition of sediments with a smaller 407 particle size distribution that are able to scavenge and retain $\mathrm{Hg}$ due to their higher surface area, 408 negative charge, and higher $\mathrm{pH}$. This site can therefore be considered a net sink for mercury 409 during the first year after the dyke was breached. The more sediment that is deposited, the larger 410 the sink will become. In contrast to considerable increases in mercury methylation observed 411 during freshwater wetland creation (Kelly et al., 1997; Sinclair et al., 2012), we observed a 27\% 412 decrease in $\mathrm{MeHg}$ concentrations in the dyke cell after the dyke was breached. This decrease 413 may have been due to greater $\mathrm{Hg}$ retention and lower $\mathrm{Hg}$ bioavailability to methylating bacteria 414 but ultimately cannot be fully explained with the available data and is limited by the low number 415 of replicate cores collected. Further work will be required to explain the precise mechanisms for 416 this decrease. 
418 Our data provides no evidence for a flush of $\mathrm{Hg}$ methylation during the first year of managed 419 retreat. As the restoration progresses and vegetation colonises, the soluble carbon concentration 420 and microbial activity may increase and the rate of $\mathrm{Hg}$ methylation may also increase. However,

421 contradictory data from other studies indicate that it is unclear whether $\mathrm{MeHg}$ will be elevated

422 beyond the concentration found in natural wetlands (Canário et al., 2007; Kelly et al., 1997;

423 Morris et al., 2014; Sinclair et al., 2012). We conclude that coastal flooding of sediments subject 424 to diffuse $\mathrm{Hg}$ contamination during managed retreat of coastal flood defences does not pose a 425 significant risk of increasing $\mathrm{Hg}$ methylation or bioavailability during the first year.

\section{Acknowledgements}

428 Financial support for this research was provided by the Canada Research Chairs, the Ducks 429 Unlimited Canada - Acadia University Partnership Grant, and an NSERC Discovery Grant 430 awarded to NJO.

\section{References}

433 Barkay, T., Gillman, M., Turner, R.R., 1997. Effects of dissolved organic carbon and salinity on bioavailability of mercury. Applied and environmental microbiology 63, 4267-4271.

435 Bengtsson, G., Picado, F., 2008. Mercury sorption to sediments: Dependence on grain size, 436 dissolved organic carbon, and suspended bacteria. Chemosphere 73, 526-531.

437 Byers, S.C., Mills, E.L., Stewart, P.L., 1978. A comparison of methods of determining organic 438 carbon in marine sediments, with suggestions for a standard method. Hydrobiologia 58, 43-47.

439 Canário, J., Caetano, M., Vale, C., Cesário, R., 2007. Evidence for elevated production of 440 methylmercury in salt marshes. Environmental science \& technology 41, 7376-7382. 
441 CCME, 2002. Canadian Sediment Quality Guidelines for the Protection of Aquatic Life.

442 Compeau, G., Bartha, R., 1985. Sulfate-reducing bacteria: principal methylators of mercury in 443 anoxic estuarine sediment. Applied and environmental microbiology 50, 498-502.

444 Covelli, S., Acquavita, A., Piani, R., Predonzani, S., De Vittor, C., 2009. Recent contamination 445 of mercury in an estuarine environment (Marano lagoon, Northern Adriatic, Italy). Estuarine, 446 Coastal and Shelf Science 82, 273-284.

447 Crowell, N., Webster, T., O'Driscoll, N.J., 2011. GIS modelling of intertidal wetland exposure 448 characteristics. Journal of Coastal Research 27, 44-51.

449 Desplanque, C., Mossman, D.J., 2004. Tides and their seminal impact on the geology, 450 geography, history, and socio-economics of the Bay of Fundy, eastern Canada. Atlantic Geology 45140.

452 Duarte, A., Pereira, M., Oliveira, J., Hall, A., 1991. Mercury desorption from contaminated 453 sediments. Water Air \& Soil Pollution 56, 77-82.

454 Emmerson, R., Birkett, J., Scrimshaw, M., Lester, J., 2000. Solid phase partitioning of metals in 455 managed retreat soils: field changes over the first year of tidal inundation. Science of the Total 456 Environment 254, 75-92.

457 Evers, D.C., Han, Y.-J., Driscoll, C.T., Kamman, N.C., Goodale, M.W., Lambert, K.F., Holsen, 458 T.M., Chen, C.Y., Clair, T.A., Butler, T., 2007. Biological mercury hotspots in the northeastern 459 United States and southeastern Canada. Bioscience 57, 29-43.

460 Gabriel, M.C., Williamson, D.G., 2004. Principal biogeochemical factors affecting the speciation 461 and transport of mercury through the terrestrial environment. Environmental geochemistry and 462 health $26,421-434$.

463 Gilmour, C.C., Henry, E.A., 1991. Mercury methylation in aquatic systems affected by acid 464 deposition. Environmental Pollution 71, 131-169. 
Gordon Jr, D.C., Baretta, J.W., 1982. A preliminary comparison of two turbid coastal ecosystems: The Dollard (Netherlands-FRG) and the Cumberland Basin (Canada). Hydrobiological Bulletin 16, 255-267.

Guédron, S., Huguet, L., Vignati, D., Liu, B., Gimbert, F., Ferrari, B., Zonta, R., Dominik, J., 2012. Tidal cycling of mercury and methylmercury between sediments and water column in the Venice Lagoon (Italy). Marine Chemistry 130, 1-11.

Haitzer, M., Aiken, G.R., Ryan, J.N., 2002. Binding of mercury (II) to dissolved organic matter: the role of the mercury-to-DOM concentration ratio. Environmental science \& technology 36, 3564-3570.

Hammerschmidt, C.R., Finiguerra, M.B., Weller, R.L., Fitzgerald, W.F., 2013. Methylmercury accumulation in plankton on the continental margin of the northwest atlantic ocean.

Environmental science \& technology 47, 3671-3677.

Haverstock, S., Sizmur, T., Murimboh, J., O’Driscoll, N.J., 2012. Modeling the photo-oxidation of dissolved organic matter by ultraviolet radiation in freshwater lakes: Implications for mercury bioavailability. Chemosphere 88, 1220-1226.

Heim, W.A., Coale, K.H., Stephenson, M., Choe, K.-Y., Gill, G.A., Foe, C., 2007. Spatial and habitat-based variations in total and methyl mercury concentrations in surficial sediments in the San Francisco Bay-Delta. Environmental science \& technology 41, 3501-3507.

Hsu-Kim, H., Kucharzyk, K.H., Zhang, T., Deshusses, M.A., 2013. Mechanisms Regulating Mercury Bioavailability for Methylating Microorganisms in the Aquatic Environment: A Critical Review. Environmental science \& technology 47, 2441-2456.

Hung, G.A., Chmura, G.L., 2006. Mercury accumulation in surface sediments of salt marshes of the Bay of Fundy. Environmental Pollution 142, 418-431.

Kelly, C., Rudd, J., Bodaly, R., Roulet, N., St. Louis, V., Heyes, A., Moore, T., Schiff, S., Aravena, R., Scott, K., 1997. Increases in fluxes of greenhouse gases and methyl mercury following flooding of an experimental reservoir. Environmental science \& technology 31, 13341344. 
Lavoie, R.A., Hebert, C.E., Rail, J.-F., Braune, B.M., Yumvihoze, E., Hill, L.G., Lean, D.R., 2010. Trophic structure and mercury distribution in a Gulf of St. Lawrence (Canada) food web using stable isotope analysis. Science of the Total Environment 408, 5529-5539.

Le Faucheur, S., Campbell, P.G.C., Fortin, C., Slaveykova, V.I., 2014. Interactions between mercury and phytoplankton: Speciation, bioavailability, and internal handling. Environmental Toxicology and Chemistry 33, 1211-1224.

Miller, W., Miller, D., 1987. A micro-pipette method for soil mechanical analysis. Communications in Soil Science \& Plant Analysis 18, 1-15.

Morris, M.A., Spencer, K.L., Belyea, L.R., Branfireun, B.A., 2014. Temporal and spatial distributions of sediment mercury in restored coastal saltmarshes. Marine Chemistry 167, 150159.

Mouneimne, S.M., Price, J.S., 2007. Seawater contamination of a harvested bog: hydrological aspects. Wetlands 27, 355-365.

O'Driscoll, N.J., Evans, R.D., 2000. Analysis of methyl mercury binding to freshwater humic and fulvic acids by gel permeation chromatography/hydride generation ICP-MS. Environmental science \& technology 34, 4039-4043.

O’Driscoll, N.J., Canário, J., Crowell, N., Webster, T., 2011. Mercury speciation and distribution in coastal wetlands and tidal mudflats: relationships with sulphur speciation and organic carbon. Water, Air, \& Soil Pollution 220, 313-326.

Ollerhead, J., Spicer, C., Bams, R., 2011. Monitoring a salt marsh restoration at Fort Beausejour, Aulac, NB - Final Report, Ducks Unlimited Canada.

Portnoy, J., Giblin, A., 1997. Effects of historic tidal restrictions on salt marsh sediment chemistry. Biogeochemistry 36, 275-303.

Powell, K.J., Brown, P.L., Byrne, R.H., Gajda, T., Hefter, G., Sjöberg, S., Wanner, H., 2005. Chemical speciation of environmentally significant heavy metals with inorganic ligands. Part 1: The Hg2+-Cl-, OH-, CO32-, SO42-, and PO43-aqueous systems (IUPAC Technical Report). Pure and applied chemistry 77, 739-800. 
Qureshi, A., O’Driscoll, N.J., MacLeod, M., Neuhold, Y.-M., Hungerbühler, K., 2009.

Photoreactions of mercury in surface ocean water: gross reaction kinetics and possible pathways. Environmental science \& technology 44, 644-649.

Rasmussen, R.S., Nettleton, J., Morrissey, M.T., 2005. A review of mercury in seafood: Special focus on tuna. Journal of Aquatic Food Product Technology 14, 71-100.

Ravichandran, M., 2004. Interactions between mercury and dissolved organic matter-a review. Chemosphere 55, 319-331.

Sinclair, K.A., Xie, Q., Mitchell, C.P., 2012. Methylmercury in water, sediment, and invertebrates in created wetlands of Rouge Park, Toronto, Canada. Environmental Pollution 171, 207-215.

Singh, K., Walters, B.B., Ollerhead, J., 2007. Climate change, sea-level rise and the case for salt marsh restoration in the Bay of Fundy, Canada. Environments: a journal of interdisciplinary studies 35 .

Sizmur, T., Canário, J., Edmonds, S., Godfrey, A., O'Driscoll, N.J., 2013a. The polychaete worm Nereis diversicolor increases mercury lability and methylation in intertidal mudflats. Environmental Toxicology and Chemistry 32, 1888-1895.

Sizmur, T., Canário, J., Gerwing, T.G., Mallory, M.L., O'Driscoll, N.J., 2013b. Mercury and methylmercury bioaccumulation by polychaete worms is governed by both feeding ecology and mercury bioavailability in coastal mudflats. Environmental Pollution 176, 18-25.

Sizmur, T., Palumbo-Roe, B., Hodson, M.E., 2011. Impact of earthworms on trace element solubility in contaminated mine soils amended with green waste compost. Environmental Pollution 159, 1852-1860.

Sunderland, E.M., Amirbahman, A., Burgess, N.M., Dalziel, J., Harding, G., Jones, S.H., Kamai, E., Karagas, M.R., Shi, X., Chen, C.Y., 2012. Mercury sources and fate in the Gulf of Maine. Environmental research 119, 27-41.

Sunderland, E.M., Gobas, F.A., Branfireun, B.A., Heyes, A., 2006. Environmental controls on the speciation and distribution of mercury in coastal sediments. Marine Chemistry 102, 111-123. 
546 Sunderland, E.M., Gobas, F.A., Heyes, A., Branfireun, B.A., Bayer, A.K., Cranston, R.E.,

547 Parsons, M.B., 2004. Speciation and bioavailability of mercury in well-mixed estuarine

548 sediments. Marine Chemistry 90, 91-105.

549 U.S.EPA, 1998. Method 7473: Mercury in solids and solutions by thermal decomposition,

550 amalgamation and atomic spectrophotometry, U.S. Environmental Protection Agency,

551 Washington, DC.

552 Ullrich, S.M., Tanton, T.W., Abdrashitova, S.A., 2001. Mercury in the aquatic environment: a 553 review of factors affecting methylation. Critical Reviews in Environmental Science and 554 Technology 31, 241-293.

555 Williams, P.B., Orr, M.K., 2002. Physical evolution of restored breached levee salt marshes in 556 the San Francisco Bay estuary. Restoration Ecology 10, 527-542.

557 Wynn, G., 1979. Late eighteenth-century agriculture on the Bay of Fundy marshlands. 558 Acadiensis, 80-89.

559

560 